\title{
PENGEMBANGAN PENGENALAN AIR DENGAN TEKNIK GAYA BEBAS UNTUK SEKOLAH DASAR
}

\author{
Bustanol Arifin \\ Pendidikan Guru Sekolah Dasar Universitas Muhammadiyah Malang \\ email: barifin@umm.ac.id
}

\begin{abstract}
Movement skills in the process of learning physical education in elementary school one of which is the basic motion of swimming. The reason why swimming branches can be used to achieve physical education goals is because swimming has many benefits. This study aims to develop the introduction of water with freestyle techniques for schools. The results of the small group trial evaluation were $78.00 \%$ for media experts, $82.08 \%$ for Penjas Learning experts, $77.79 \%$ for Pool experts and $90.90 \%$ for Penjas learning experts. in the large group test using 30 students obtained a percentage of $90.15 \%$, based on these results the development model of water recognition with freestyle techniques for schools can be used in the learning process.
\end{abstract}

\section{Keywords: Improvement, Basic Swimming Stroke, Elementary School}

\begin{abstract}
Abstrak: keterampilan gerak dalam proses pembelajaran pendidikan jasmani di sekolah dasar salah satunya adalah gerak dasar renang. Alasan mengapa cabang renang dapat digunakan untuk mencapai tujuan pendidikan jasmani adalah karena renang memilki banyak manfaat. Penelitian ini bertujuan mengembangkan pengenalan air dengan teknik gaya bebas untuk sekolah. Hasil evaluasi uji coba kelompok kecil 78,00\% untuk ahli media, 82,08\% untuk ahli Pembelajaran Penjas, 77,79\% untuk ahli Renang dan 90,90\% untuk ahli pembelajaran penjas. pada uji kelompok besar dengan menggunakan 30 siswa diperoleh persentase $90,15 \%$, berdasarkan hasil tersebut model pengembangan pengenalan air dengan teknik gaya bebas untuk sekolah dapat digunakan dalam proses pembelajaran.
\end{abstract}

Kata kunci: Pengembangan, pengenalan air, sekolah dasar

\section{PENDAHULUAN}

Pendidikan merupakan usaha sadar dan terencana untuk mewujudkan suasana belajar dan proses pembelajaran agar peserta didik secara aktif mengembangkan potensi dirinya untuk memiliki kekuatan spiritual keagamaan, pengendalian diri, kepribadian, kecerdasan, akhlak mulia, serta keterampilan yang diperlukan dirinya, masyarakat, bangsa dan negara.

Pendidikan jasmani memiliki sasaran pedagogis, oleh karena itu pendidikan kurang lengkap tanpa adanya pendidikan jasmani, karena gerak sebagai aktivitas jasmani adalah dasar bagi manusia untuk mengenal dunia dan dirinya sendiri yang secara alami berkembang searah dengan perkembangan zaman. Pendidikan jasmani merupakan suatu pendidikan dimana dalam mencapai tujuan pendidikan menggunakan sarana gerak tubuh/jasmani. Melalui gerak tersebut akan dapat ditanamkan beberapa nilai pada siswa, seperti nilai sosial, moral dan lain-lain. Melalui gerak itu pula, tujuan pendidikan akan dapat dicapai. Tujuan pendidikan jasmani adalah untuk meningkatkan pertumbuhan dan perkembangan anak didik yang menyangkut kogntif, afektif, psikomotor, dan fisik.

Pendidikan jasmani yang dilaksanakan di sekolah pada umumnya bertujuan memberikan aktivitas gerak yang bisa berupa permainan, senam, atletik, renang, atau beladiri. Badan Standart Nasional Pendidikan (2006:648) menyatakan bahwa Pendidikan Jasmani Olahraga dan Kesehatan merupakan bagian integral dari pendidikan secara keseluruhan, bertujuan untuk 
mengembangkan aspek kebugaran jasmani, keterampilan gerak, keterampilan berfikir kritis, keterampilan sosial, penalaran, stabilitas emosional, tindakan moral, aspek pola hidup sehat, dan pengenalan lingkungan bersih melalui aktifitas jasmani, olahraga dan kesehatan terpilih yang direncanakan secara sistematis dalam rangka mencapai tujuan pendidikan nasional.

Tujuan pendidikan jasmani dapat tercapai dengan adanya beberapa komponen penting antara lain, tujuan pengembangan, guru, siswa, serta fasilitas lainnya (misalnya media, sarana dan prasarana). Hal tersebut dikarenakan proses belajar mengajar harus sesuai dengan kondisi kelas maupun sekolah masing-masing, sehingga proses transformasi keterampilan motorik antara guru dan siswa dapat tercapai.

Tujuan pendidikan jasmani di sekolah dasar diantaranya adalah mengembangkan keterampilan pengelolaan diri dalam upaya pengembangan dan pemeliharaan kebugaran jasmani serta pola hidup sehat melalui berbagai aktivitas jasmani dan olahraga yang terpilih, meningkatkan pertumbuhan fisik dan pengembangan psikis yang lebih baik, meningkatkan kemampuan dan keterampilan gerak dasar, meletakkan landasan karakter moral yang kuat melalui internalisasi nilai-nilai yang terkandung di dalam pendidikan jasmani, olahraga dan kesehatan, mengembangkan sikap sportif, jujur, disiplin, bertanggung jawab, kerjasama, percaya diri dan demokratis, mengembangkan keterampilan untuk menjaga keselamatan diri sendiri, orang lain dan lingkungan, memahami konsep aktivitas jasmani dan olahraga di lingkungan yang bersih sebagai informasi untuk mencapai pertumbuhan fisik yang sempurna, pola hidup sehat dan kebugaran, terampil, serta memiliki sikap yang positif.

Cabang olahraga yang dapat digunakan untuk mencapai tujuan tersebut, di antaranya adalah cabang olahraga renang. Alasan mengapa cabang renang dapat digunakan untuk mencapai tujuan pendidikan jasmani adalah karena renang memilki banyak manfaat. Manfaat tersebut diantaranya dapat membantu pertumbuhan dan perkembangan tubuh, bersosialisasi dan berinteraksi dengan orang lain, menambah kepercayaan pada diri sendiri, dan dapat digunakan sebagai kegiatan rekreatif karena rangsangan dingin dapat menyegarkan tubuh dan perasaan. Belajar renang juga dapat menambah pengetahuan siswa tentang gerak yang efektif dan efisien, sifat-sifat air, teori renang dan lain-lain. Karena beberapa manfaat tersebut diatas maka saat ini renang sudah dimasukkan dalam dunia pendidikan mulai dari SD sampai SMA untuk itulah penulis berkesempatan akan menyajikan model-model pengembangan gerak dasar renang untuk sekolah dasar.

\section{METODE}

Peneliti menggunakan sepuluh langkah dari Borg \& Gall, Adapun bentuk dari metode pengembangan pengenalan air dengan teknik gaya bebas untuk sekolah dasar adalah sebagai berikut: (a) Penelitian dan pengumpulan data dalam penelitian awal atau analisis kebutuhan (need assessment) dengan cara menyebarkan angket dan observasi (wawancara) kepada guru PJOK SD Mohammad Hatta Malang, (b) Perencanaan (pendefinisian keterampilan penentuan urutan pengajaran), (c) Pengembangan draf produk berupa rancangan produk, (d) Evaluasi ahli (dilakukan oleh beberapa ahli), (e) Uji coba lapangan awal (dilakukan pada siswa kelas 4 dengan menggunakan 8 subjek yang diambil secara acak), (f) Merevisi hasil uji coba (sesuai dengan saran-saran hasil uji coba lapangan permulaan), (g) Uji coba lapangan utama (dilakukan pada siswa kelas 4 dengan menggunakan 30 subjek yang diambil secara acak), (h) Penyempurnaan hasil uji 
coba lapangan utama (revisi produk berdasarkan saran-saran dari hasil uji coba lapangan utama), (i) uji efektifitas model (dilakukan pada siswa kelas 4 dengan menggunakan 30 subjek yang diambil secara acak).

\section{HASIL DAN PEMBAHASAN}

Data hasil analisis kebutuhan dengan persentase sebanyak guru PJOK SD Mohammad Hatta Malang belum maksimalnya dalam pembelajaran PENJAS secara khusus dimateri Aquatik.

\section{Analisis Data Evaluasi Ahli Media}

Hasil analisis yang telah dilakukan terhadap tanggapan/penilaian dari ahli media, hasilnya adalah $\mathbf{7 8 , 0 0 \%}$, dari kriteria yang ditentukan dan dapat dikatakan bahwa pengembangan pengenalan air dengan teknik gaya bebas untuk sekolah dasar ini memenuhi kriteria CUKUP VALID (60\%-79\%) sehingga dapat digunakan dan dipraktekkan pada uji coba lapangan/ kelompok besar.

\section{Analisis Data Evaluasi Ahli pembelajaran PENJAS}

Hasil analisis yang telah dilakukan terhadap tanggapan/penilaian dari ahli pembelajaran renang, hasilnya adalah 82.08\%, dari kriteria yang ditentukan dan dapat dikatakan bahwa pengembangan pengenalan air dengan teknik gaya bebas untuk sekolah ini memenuhi kriteria VALID (80\%-100\%) sehingga dapat digunakan dan dipraktekkan pada uji coba lapangan/ kelompok besar.

\section{Analisis data Evaluasi Ahli Renang}

Hasil analisis yang telah dilakukan terhadap tanggapan/penilaian dari ahli permainan, hasilnya adalah

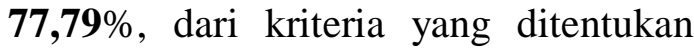
dan dapat dikatakan bahwa pengembangan pengenalan air dengan teknik gaya bebas untuk sekolah dasar ini memenuhi kriteria CUKUP VALID
(60\%-79\%) sehingga dapat digunakan dan dipraktekkan pada uji coba lapangan/ kelompok besar.

\section{Analisis data Pada Uji Coba kelompok Besar}

Hasil uji coba kelompok besar yang telah dilakukan hasilnya adalah $\mathbf{9 0 , 1 5 \%}$, dari kriteria yang ditentukan dan dapat dikatakan bahwa pengembangan pengenalan air dengan teknik gaya bebas untuk sekolah ini memenuhi kriteria VALID (80\%-100\%) sehingga dapat digunakan dan dipraktekkan dalam proses pembelajaran.

\section{Data renang dasar gaya bebas}

Teknik analisis uji-t amatan ulangan digunakan untuk menghitung perbedaan dua mean untuk sampel yang berhubungan atau sampel tak mandiri (dependent sample). Sedangkan dalam penelitian ini yang diuji adalah suatu perlakuan (treatment) eksperimen pengembangan pengenalan air dengan teknik gaya bebas untuk sekolah dasar yang dikenakan terhadap satu kelompok obyek penelitian yaitu siswa sekolah dasar SD Mohammad Hatta yang berjumlah 30 siswa dan dipilih secara acak. Sebelum dan sesudah perlakuan dilakukan pengukuran, selanjutnya antara dua data pengukuran tersebut dianalisis dengan uji-t. dari hasil analisis dapat diketahui perbedaan antara dua mean tes awal dan tes akhir. Dengan kata lain dapat diketahui efektivitas perlakuan eksperimen.

Hasil penelitian uji efektivitas, dapat disimpulkan hasil penelitian uji signifikasi t hitung $=33,953>\mathrm{t}$ tabel $5 \%$ 2,045 dengan derajat kebebasan 30-1=29. Karena $\mathrm{t}$ hitung lebih besar daripada $\mathrm{t}$ tabel maka hipotesis nihil ditolak. Kesimpulannnya ada perbedaan yang signifikan antara tes awal dan tes akhir. Dengan kata lain pengembangan pengenalan air dengan teknik gaya bebas untuk sekolah dasar memiliki efektivitas yang baik untuk meningkatkan 
kemampuan dasar renang siswa sekolah dasar.

\section{Kesimpulan}

Pengembangan gerak dasar renang untuk sekolah dasar merupakan bagian dalam proses pembelajaran yang ada dalam sekolah dasar yang bertujuan untuk membantu pertumbuhan dan perkembangan tubuh, bersosialisasi dan berinteraksi dengan orang lain, menambah kepercayaan pada diri sendiri, dan dapat digunakan sebagai kegiatan rekreatif karena rangsangan dingin dapat menyegarkan tubuh dan perasaan.

Model pengembangan gerak dasar renang di sekolah dasar harus disesuaikan dengan tahap pertumbuhan dan perkembangan anak agar hasil yang dicapai sesuai dengan tujuan pembelajaran yang diinginkan.

\section{SARAN}

Dalam mengembangkan penelitian ini ke arah lebih lanjut, peneliti mempunyai beberapa saran, sebagai berikut:

1. Pengembangan gerak dasar renang bagi siswa khususnya sekolah dasar dapat diterapkan sebagai pembelajaran aquatik

2. Perlu adanya pengembangan lebih lanjut teknik gerak dasar renang

\section{DAFTAR PUSTAKA}

Mudayat. (2010). Pembelajaran dan Perkembangan Motorik. Sekolah Tinggi Keguruan dan Ilmu Pendidikan persatuan Guru Republik Indonesia Pontianak.

Sukintaka. (1992) Teori Bermain untuk PGSD Penjaskes. Jakarta: Depdikbud.

Suryatna, E. (2001) Renang Kompetitif alternatif untuk SLTP. Jakarta. DEPDIKNAS.
Syarifuddin, Aip dan Muhadi. (1992) Pendidikan Jasmani dan Kesehatan. Jakarta: Depdikbud. 